\title{
STRATIGRAPHIC SECTIONS IN THE STE. GENEVIEVE FORMATION (MIDDLE MISSISSIPPIAN) EXPOSED IN GARRISON CHAPEL KARST AREA CAVERNS - WESTERN MONROE COUNTY, INDIANA USA
}

\author{
Garre A. Conner *
}

SUMMARY

The Ste. Genevieve Formation and related strata in the Blue River Group comprise more than 75 meters of Middle Mississippian carbonate deposition across the Indiana portion of the Eastern Interior Basin in Valmeyeran seaways. Forty kilometers of subterranean caverns occur in this carbonate rock sequence in the Garrison Chapel karst area where blind valleys are a striking topographical feature. The bedrock floor of a karst valley is locally accordant with a continuous horizon of lithographic limestone named Indian Creek Beds and illustrated on five cavern stratigraphic reference profiles.

\section{INTRODUCTION}

The Garrison Chapel karst area in western Monroe County, Indiana has been a popular area of subterranean exploration and scientific investigations pertaining to cavern origin and development. More than 40 kilometers of subterranean streams and canyons have been surveyed from water catchment sinkholes and blind valleys downward to the spring resurgences. These caverns lie along the western margin of a distinctively karst erosional valley occupying 35 square kilometers located southwest of Bloomington, Indiana in the Crawford Upland physiographic province (MALOTT, 1922, p. 197-203). The Garrison Chapel karst area of about 10 square kilometers and the karst valley at the headlands of Indian Creek are illustrated in Fig. 1.

The bedrock host or floor of this karst valley consisting of sinkholes and downstream segments of sinking streams is locally accordant with a solutionally incised horizon of lithographic limestone that is laterally continuous throughout the headland area of Indian Creek. The lithographic limestone beds are generally 3 to 5 meters thick, thin and evenly bedded

\footnotetext{
* Consultant Geologist U.S.A. P.O. Box 333, Evansville, Indiana 47701
} 


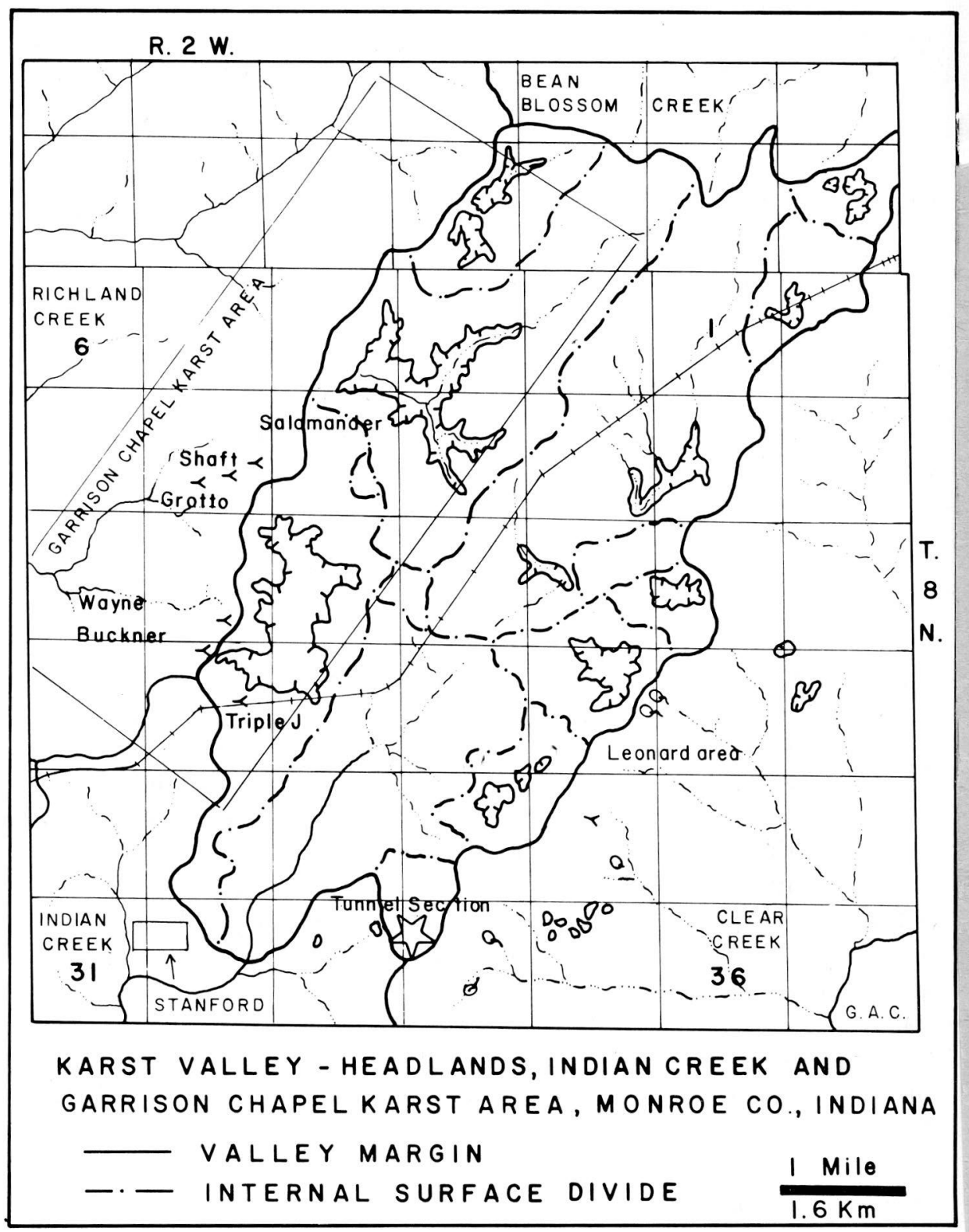

Fig. 1 - Karst valley -headlands, Indian Creek and Garrison Chapel karst area, Monroe Co., Indiana. 


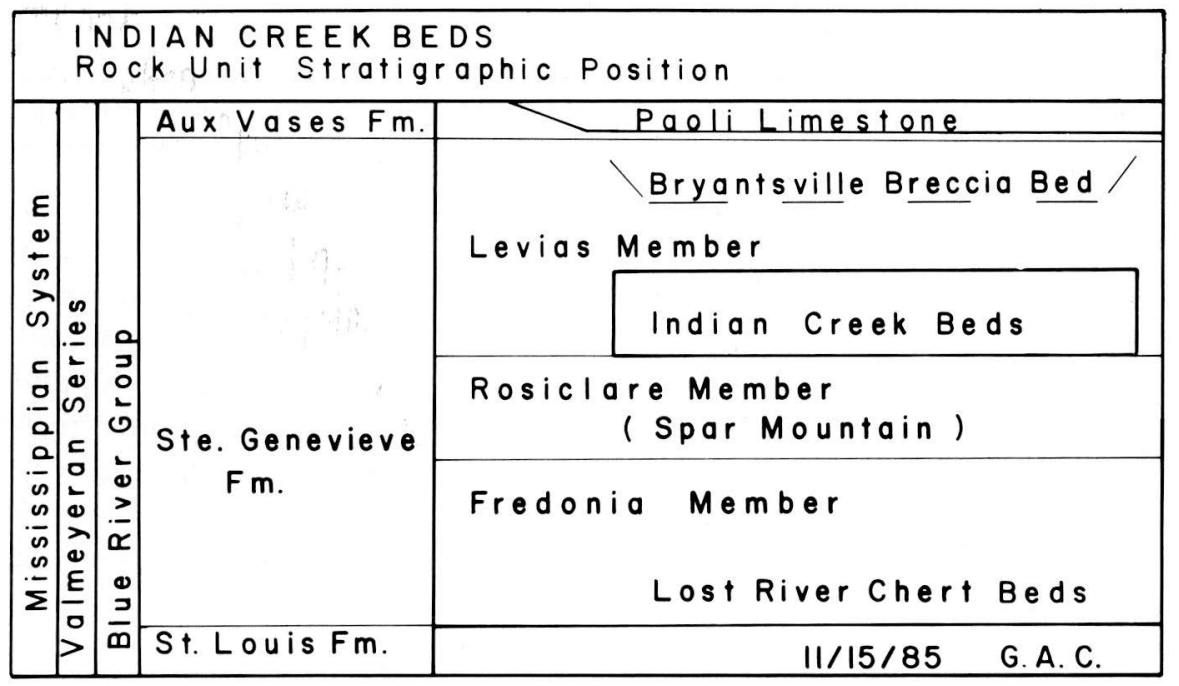

Fig. 2 - Indian Creek Beds: Rock unit stratigraphic position.

cryptocrystalline micrite. They are white with tan and green clay stains. Clay intercalations occur along bedding planes and vertical fractures are filled with clay and recrystallized calcite. Styolites are observed at some exposures coinciding with bedding planes. Stratified nodular chert may be present at some exposures. The lithographic texture distinguishes these strata essentially comprising the lower half of the Levias Member of the Ste. Genevieve Formation. The Ste. Genevieve Formation in the Blue River Group is middle Mississippian in age. These lithographic beds are named the Indian Creek Limestone Beds (ConNeR, 1986) (Fig. 2).

Recognition of the Indian Creek Beds as a mappable unit is attributed in part to exposures in cavern sections in the Garrison Chapel karst area and comparison to established surface exposures described in the literature. Five measured stratigraphic reference sections in cavern exposures associated with the karst valley are presented with this investigation and illustrate the cycle of subterranean cavern development and related surface valley drainage accordance with the structural form the the Indian Creek Beds (Fig. 3).

\section{THE GARRISON CHAPEL KARST AREA}

The Garrison Chapel karst area (Fig. 4) described in the Convention Guidebook of the National Speleological Society (1973, p. 16-34), refers 
generally to four major subterranean cavern systems. These westward draining caverns are oriented along the strike axis of the karst valley from Garrison Chapel southward to the Illinois Central Railway grade. The northern most cavern system considered here is comprised of the hydrologically integrated streams flowing through Salamander, Shaft, Grotto and Coons Caves. Wayne and Buckner Cave lie to the south as separate hydrological drainage systems. Farthest south is the Blair Springs system comprised of Triple J, Brinegar, Trap Door, and King Blair Caves. Many smaller caves are related to these systems. Other major systems lie to the north and east of this area of the karst valley, but were not included in this investigation. POWELL (1960) published a statewide survey of known caverns in Indiana. The periodical Newsletter of the Bloomington Indiana Grotto is an important source for articles and maps pertaining to caverns of the Garrison Chapel area.

\section{RECOGNITION OF THE KARST VALLEY}

The fifteen minute topographical map of the Bloomington quadrangle (MARSHALL, 1910), revealed the karst landforms in the headlands of Indian Creek. J. W. BEEDE (1911), investigated the origin of the karst valley there with description of the area including the Garrison Chapel

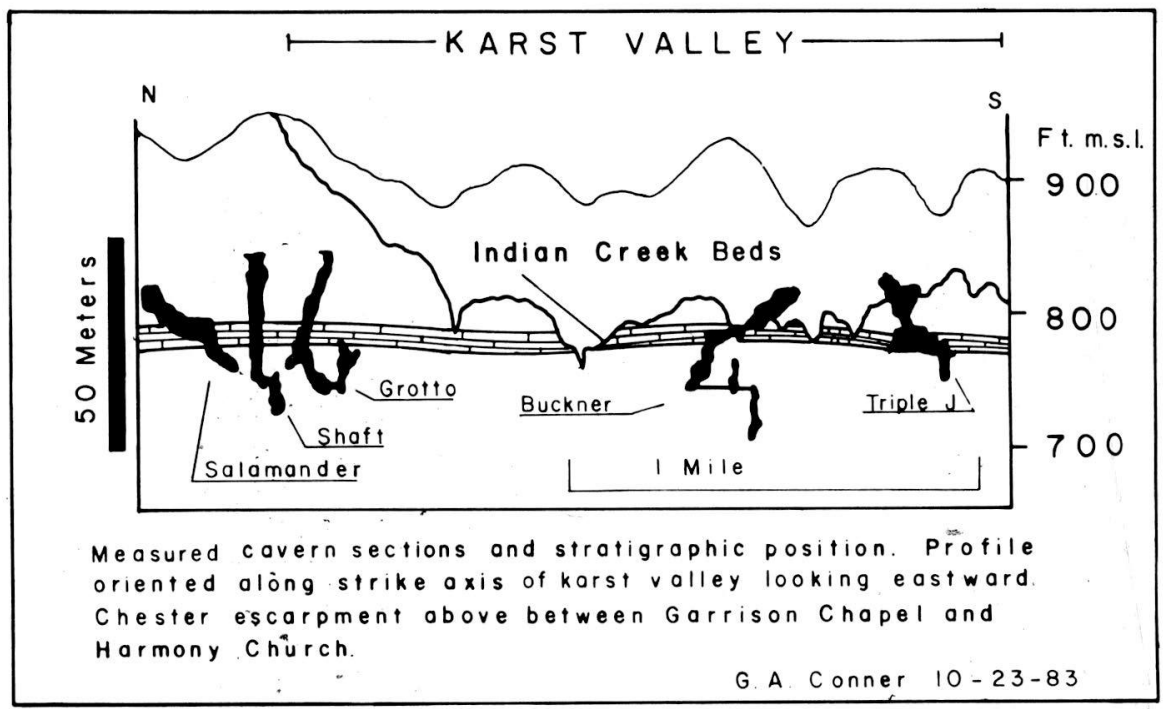

Fig. 3 - Measured cavern sections and stratigraphic position. 


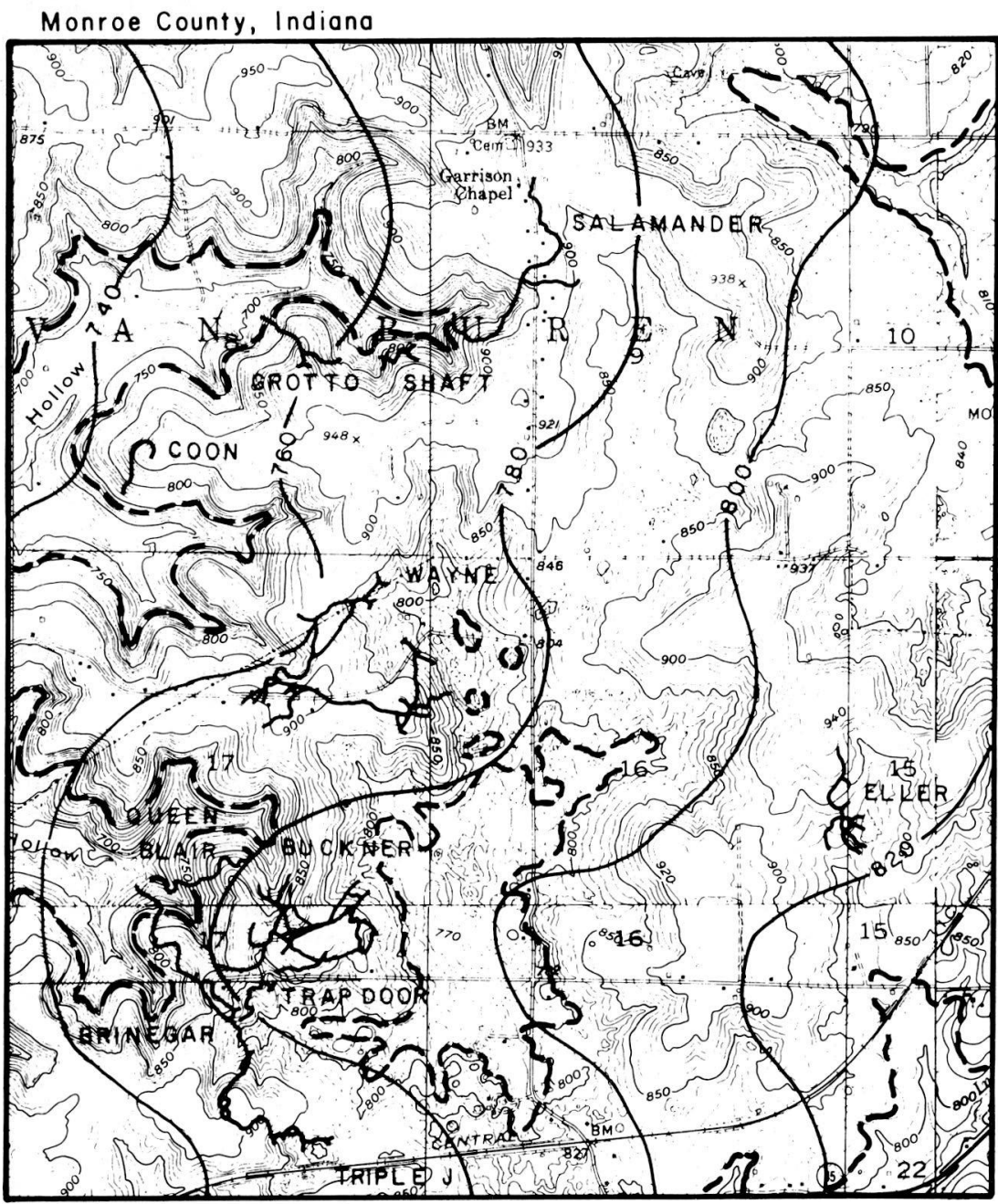

Base modified 1973 Convention Guidebook, National Speleological Society

Contours - Ft. mean sea.
- Out-crop of Indian Creek Beds based on altimeter reodings, G. A. Conner

I Kilometer

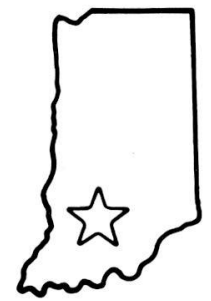

Fig. 4 - Indian Creek Beds structure contours in karst valley. 
area while focusing on the eastern side of the valley in the area of Leonard Springs. The springs and related landforms were illustrated with photographs and a pen sketch revealing Beede's interpretation of subterranean stream piracy. Sinkholes above the caverns intercept surface waters from short segments of Indian Creek diverting them downward and southwestward under the Garrison Chapel area through cave streams discharging into Richland Creek. Trending in the opposite direction other cave streams flow southeastward below the Leonard area discharging waters into Clear Creek to the east.

C. A. MALOTT (1922) described the landforms and drainage related to the karst valley of Indian Creek and the related phenomen of subterranean stream piracy. MALOTT's sketch map outlined the entire karst valley showing internal surface drainage divides and sinkhole in the blind valleys similar to the outlines in Fig. 1. The origin and age of the karst valley were discussed by MALOTT in relation to the Kirksville Peneplain (MALOTT, 1919, p. 23) of the region. Stratigraphic names Paoli and Ste. Genevieve Limestone were in use at that time, but MALOTT's reference to the strata employed the earlier terms Mitchell Limestone and the overlying Coal Measures of the Carboniferous strata.

W. J. WAYNE (1949) described a karst plane or sinkhole plane as a region underlain by limestone in which all of the drainage is underground. Wayne's map illustrated principally the same area as MALOTT's map. WAYNE discussed the jointed and oolitic nature of the Paoli and Ste. Genevieve limestones; stating the operational stream piracy of the headwaters of Indian Creek by Richland and Clear Creeks.

\section{STRATIGRAPHIC NOMENCLATURE FOR THE CAVERN SECTIONS}

Stratigraphic names employed in the illustrations of the measured rock sections in the caverns represent (Fig. 2) units of current use in rockunit stratigraphy in Indiana.

Emphasis on the word member in the stratigraphic sense, used here, for measured sections rather than the words limestone or sandstone following a proper name is intended to maintain conformity with established nomenclature for the Blue River Group in Indiana while omitting an exiguous and reiteratitive discussion of the attendant nomenclatural revisions over past decades.

The Blue River Group established by GRAY \& AL. (1960), includes in ascending order the St. Louis and Ste. Genevieve Formations succeeded 
by the Paoli Limestone. Divisions of the Ste Genevieve Formation include the Fredonia Member, with the Lost River Chert Bed, the Rosiclare Member, and the Levias Member including the Indian Creek Beds and the Bryantsville Breccia Bed at the top.

The term Spar Mountain Member of Illinois use has been synonymously substituted for the Rosiclare Member of Indiana which has been agreeably accepted by most investigators.

The Paoli Limestone and lower sandy beds were considered by N. M. Smith (SHAVER ET AL., 1970; p. 125-128), to be the out-crop equivalent of the Renault Formation. The lower sandy beds were consistently recorded at Indiana exposures under the name Aux Vases sandstone by MALOTT (1952) and by PERRY \& SMITH (1958). Later an exposure of this unit in Lawrence County Indiana was named Popcorn Sandstone Bed by SWANN (1963, p. 31 -32). The Popcorn Bed is continuous through the Garrison Chapel area as a calcareous sandstone and shale, but is less than $2.5 \mathrm{~cm}$. in thickness in many exposures there. Illustrated on the figures it is not labeled at its position overlying the Bryantsville Breccia Bed.

\section{DESCRIPTION OF THE CARBONATE AND RELATED LITHOLOGIES}

A legend of the lithologic and stratigraphic characteristics of the Blue River Group exposed in the caverns is illustrated in Fig. 5. Legend symbols represent the main lithotypes, bedding, and jointing characteristics which allow the beds to be recognized and correlated among isolated exposures.

Carbonate rocks were classified by relative size of crystallinity, grainstone component, and cementation. Sparite generally refers to a cementing material or cavity filling. Crystal size was not directly measured during microscopic examination of hand samples. Granular is a term applied to dolostones, but also to certain calcite and partially dolomitized beds. Micrite was recognized in crystalline and detrital modes, but this detail was omitted from the descriptions substituting the terms crystalline or granular.

Algal structures and related sub-areal laminated crust were frequently observed in the top of the Levias associated with the Bryantsville Breccia Bed. Low and steeply inclined joints were commonly exhibited in the oolitic and bioclastic beds in the upper half of the Levias Member and the Paoli Limestone. Thin laminar and cross laminar bedding is characteristic of the sandy beds in the Spar Mountain Member. Massive argillaceous detri- 


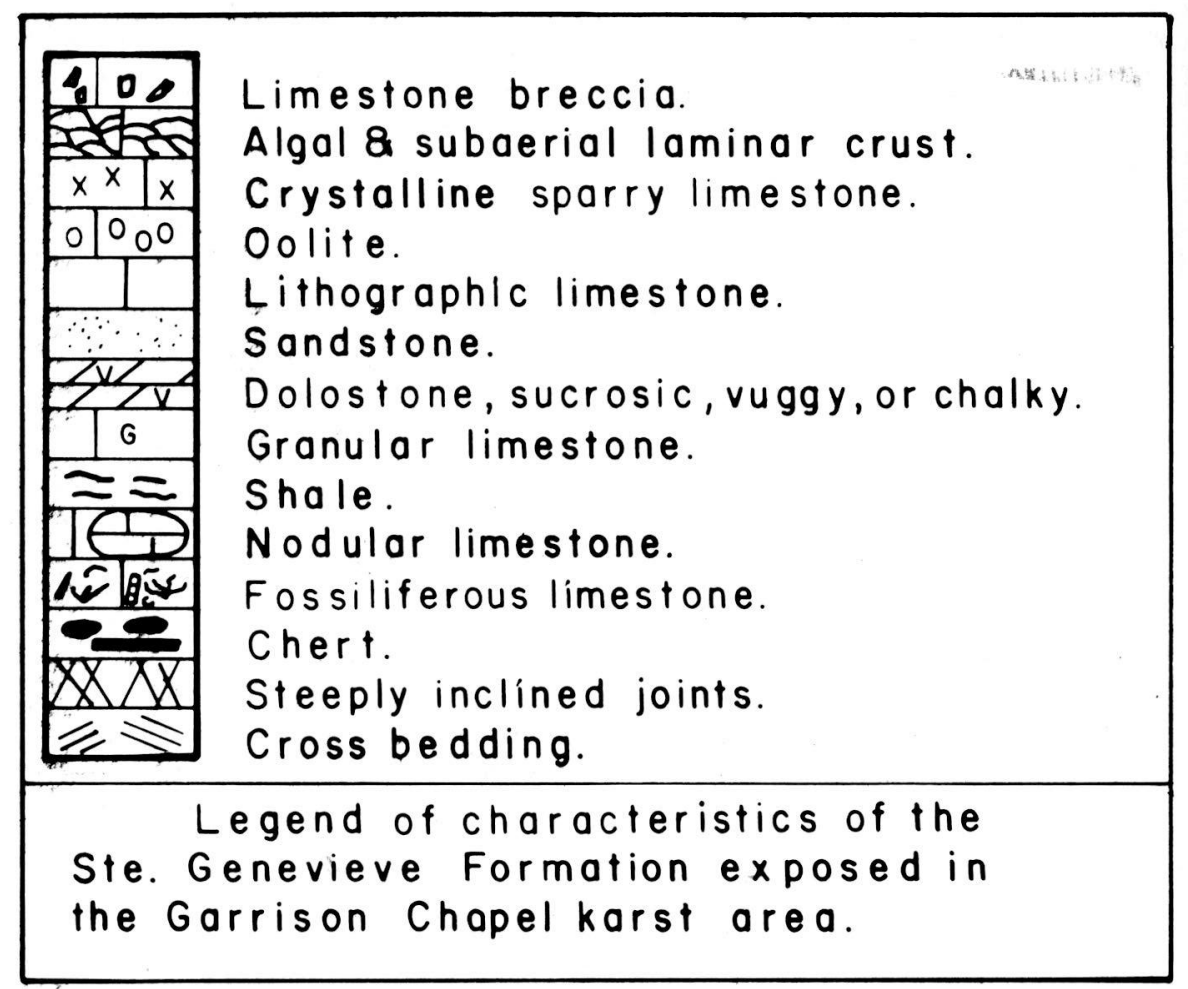

Fig. 5 - Legend of stratigraphic symbols for Ste. Genevieve Fm.

tal limestones with nodular chert and silty laminations are typical of the Fredonia Member including dolostone beds.

\section{DESCRIPTION OF MEASURED CAVERN SECTIONS}

Description and measurement of the carbonate rock sections in the caverns were made at Breakdown Mountain in Salamander Cave (Fig. 6); the entrance and lower offset pit in Shaft Cave (Fig. 7); the entrance and offset chambers in Grotto Cave (Fig. 8); entrance, Signature Room, and waterfall in Buckner Cave (Fig. 9); and the entrance crevice in Triple J Cave (Fig. 10).

Bedrock surfaces exposed in cavern walls and shafts are frequently more amenable to recognition of various lithologies than corresponding surface exposures. Surface frost wedging, vegetation, and direct sunlight 
are not a major influence on modification of cavern walls that are sculptured by water or gravity fall of jointed blocks.

Irregularities and surface relief exposed on the cavern walls results from solution features which are generally smooth and curved or from breakdown falls which leave straight and angular fracture surfaces. Both types of features reveal some degree of surficial leaching as a response to differential moisture after the bed is left above the high water level of the cave stream.

Individual beds or groups of beds are observed to stand in relief from the plane of the wall or are reentrant. The reentrant zones are recessed behind the wall plane. Harder and more indurated carbonates and those high in insoluble grains as well as the more coarsely crystalline beds tend to stand in relief from walls in contrast to the oolitic and bioclastic beds. Clayey shales tend to be more reentrant where plastic flow, pressure unloading, and differential moisture influence them.

Sandstones and silty shales usually are exposed in relief from the walls, but are not always conspicuous. Dolostone is usually found in relief and is often sculptured into erosional forms extending across the entife width of canyons as bridges because of its lower solubility rate and a pro-

\section{SALAMANDER CAVE Monroe Co., Indiana}

BREAKDOWN MOUNTAIN

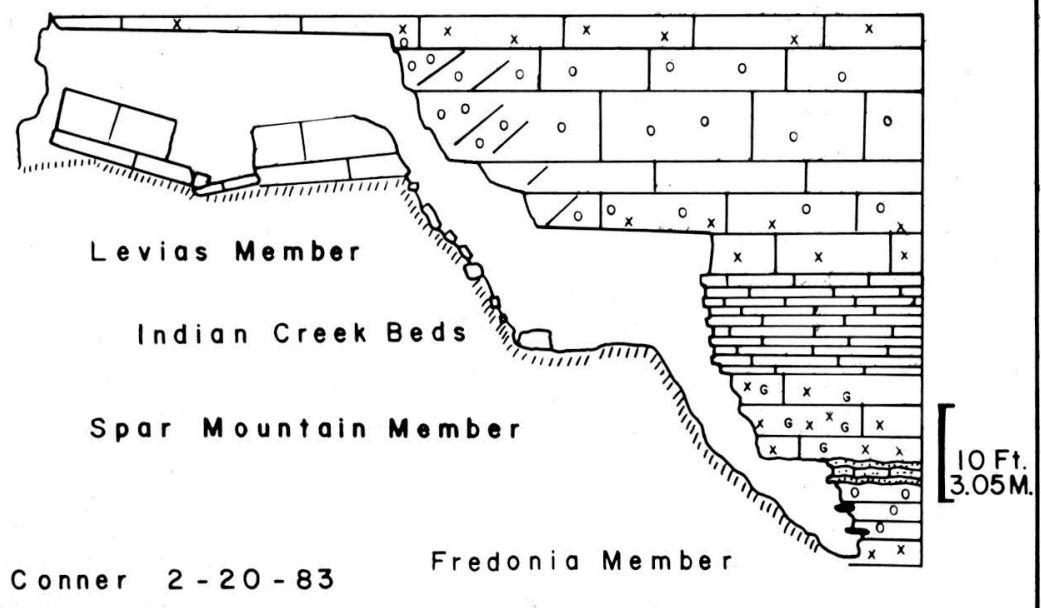

Fig. 6 - Salamander Cave section. 
SHAFT CAVE Monroe Co., Indiana

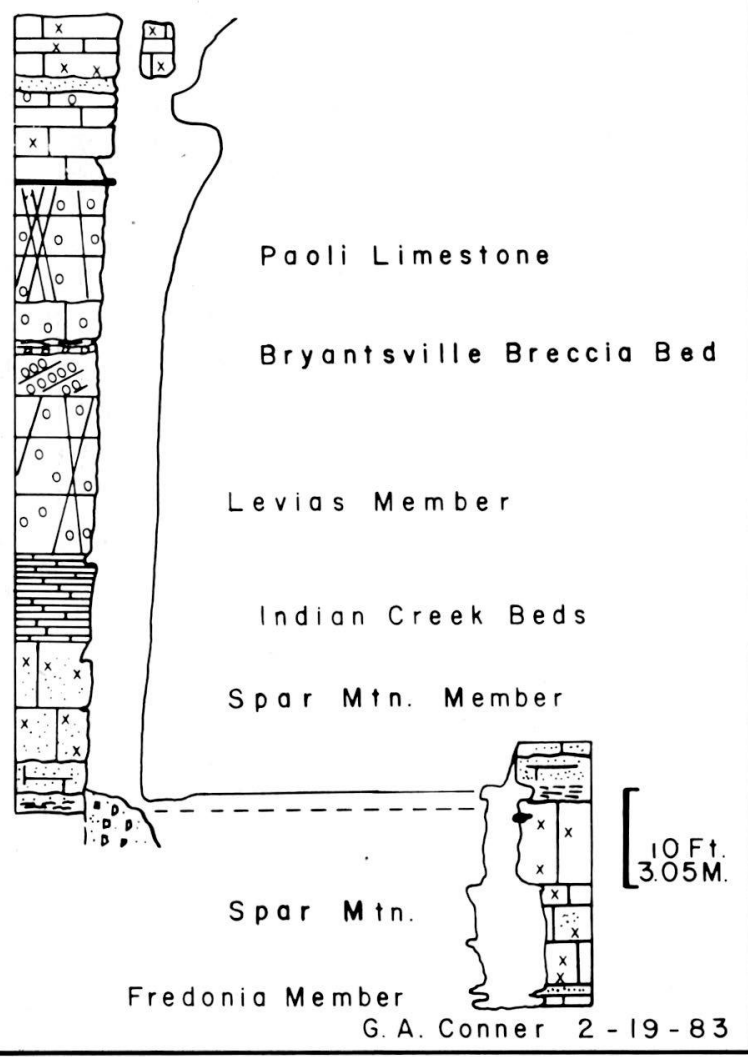

pencity to become coated with precipitated carbonate and manganese dioxide. Where dolostone is not coated it typically developes a soft chalky surface. Carbonate precipitated on cavern walls results in various forms referred to as speleothems frequently covers silty or sandy beds where porosity permits water seepage. Wall forms are important in recognizing the textural types of carbonate strata when tracing from one reference section to the next.

Breakdown Mountain in Salamander Cave (Fig. 6) is located about $150 \mathrm{~m}$. upstream from the entrance and is generally accessable except for rapid short term crest during thunderstorms. The section profile is drawn facing outward or downstream. A floor elevation of $227 \mathrm{~m}$. mean tide was 
established by Paulin altimeter. The lower canyon walls reveal the top sandy beds of the Spar Mountain Member exposed nine feet above the floor. The Indian Creek Beds in the lower Levias Member above measure $2.9 \mathrm{~m}$. in thickness with the base resting on the Spar Mountain. Above in the breakdown chamber the oolitic, bioclastic and jointed beds of the upper Levias Member are well exposed in the ceiling. The Bryantsville Breccia Bed was not observed, but would lie several feet above the ceiling.

The entrance pit to Shaft Cave (Fig. 7) is located about $180 \mathrm{~m}$. southwest of Breakdown Mountain in Salamander Cave. The entrance lies at an elevation of $251 \mathrm{~m}$. mean tide and drops $23 \mathrm{~m}$. to a canyon developed in the middle of the Spar Mountain Member leading to an offset lower pit 9 m. away where 6 meters of strata are exposed down to a lower stream canyon in the top of the Fredonia Member. At the top of the entrance pit a finely crystalline micritic limestone is exposed. Below the lip of the pit $0.75 \mathrm{~m}$. of calcareous sandstone is exposed consisting of brown weathered very fine grained quartz. The stratigraphic names of these two units is discussed in the summary of correlations. The Paoli Limestone measures 7.1 m. thick. The lower sandy bed, the Popcorn Bed of Swann, is obscured by flowstone, but measures $9.1 \mathrm{~cm}$. thick resting on the Bryantsville Breccia Bed. The entire Levias Member measures $9 \mathrm{~m}$. thick with the Indian Creek Beds comprising $2.9 \mathrm{~m}$. The Spar Mountain Member measures $10.4 \mathrm{~m}$. including a thin silty bed near the floor of the lower pit. Below, one foot of finely crystalline limestone is exposed in the floor of the stream canyon marking the upper unit of the Fredonia Member. Shaft may be entered safely in dry weather with modern rope ascending equipment.

Grotto Cave section (Fig. 8) was measured in the entrance chamber about $180 \mathrm{~m}$. southwest from Shaft. A steep slope decends to a small dome and adjacent chamber where the section was continued. The surface reference elevation was $244 \mathrm{~m}$. mean tide measured with Paulin Altimeter. From there $6 \mathrm{~m}$. of Paoli Limestone was measured downward to a $3 \mathrm{~cm}$. grey silty lamination marking the Popcorn Bed. No Bryantsville Breccia was observed. The silty unit rest directly on a micritic bioclastic bed of upper Levias Member. The Levias measures $9.5 \mathrm{~m}$. feet including $2.8 \mathrm{~m}$. of Indian Creek Beds exposed at the boulder which must be climbed over in decent near the bottom of the chamber. The exposed section of Spar Mountain measures $8.6 \mathrm{~m}$. from the base of the Indian Creek Beds to the top of the Fredonia $22 \mathrm{~m}$. away in the adjacent chamber. The top and base of the Spar Mountain Member are marked by thin resistant sandy lentils in relief. These sandy lentils are exposed in the adjacent chamber, but were 


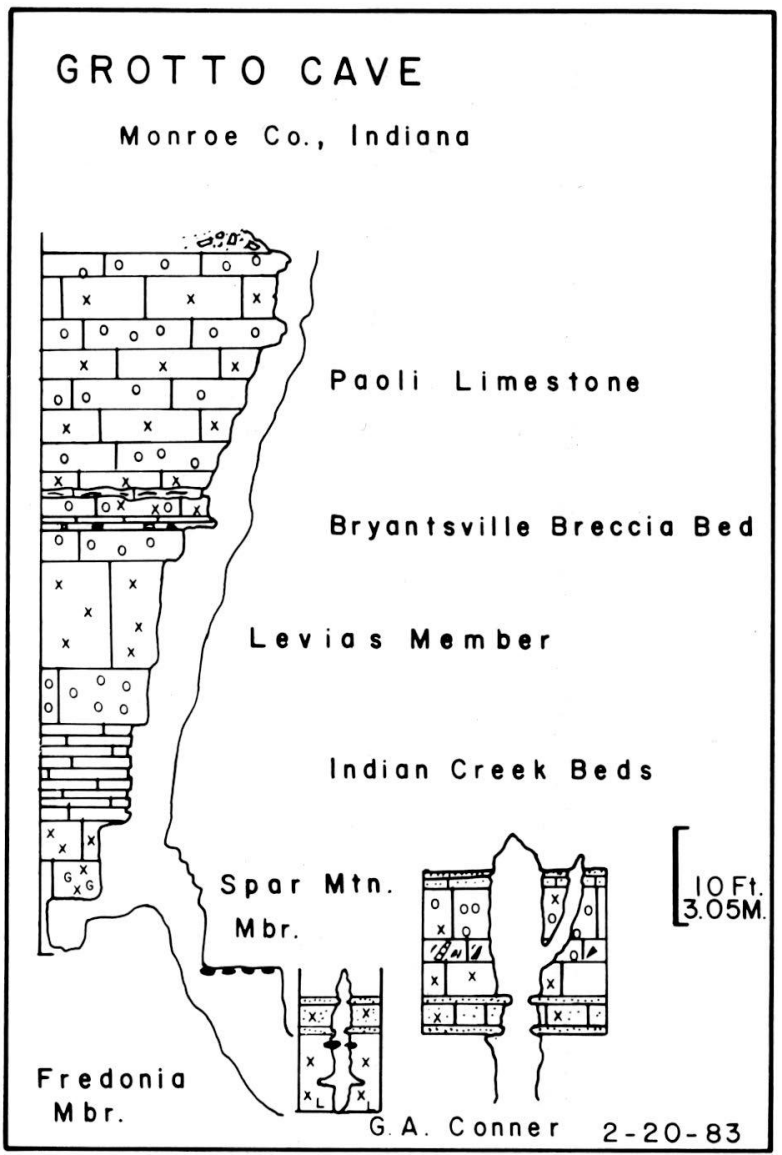

Fig. 8 - Grotto Cave section.

not observed in the entrance chamber. Instead in the lower part of the entrance chamber there is $1.9 \mathrm{~m}$. of argillaceous limestone exposed, with no sand, immediately below the Indian Creek Beds. Again as at Salamander these argillaceous beds are included in the Spar Mountain Member in an effort to establish the base of the Indian Creek Beds in contact with the Spar Mountain Member. The sandy lentils in the adjacent chamber include three modes of detrital quartz.

Buckner Cave section (Fig. 9) lying $1.8 \mathrm{~km}$. to the south is an extended vertical profile starting at the entrance, elevation $247 \mathrm{~m}$. mean tide, continuing downward through the crawlway and Signature Room then through the stream canyon to the base of the waterfall. There is $0.9 \mathrm{~m}$. of 
Paoli Limestone exposed in the ravine above the entrance. The Popcorn Bed measures $15 \mathrm{~cm}$. of silty shale and the micritic laminar crusts of the Bryantsville Breccia Bed form the ceiling. The Levias Member measures $11.3 \mathrm{~m}$. including $3.7 \mathrm{~m}$. of Indian Creek Beds. Near the Signature Room the base of the Indian Creek Beds is well exposed near the ceiling where $2.4 \mathrm{~m}$. of slightly sandy crystalline limestone underlies them marking the contact with the Spar Mountain Member. The entire Spar Mountain Member measures $4.9 \mathrm{~m}$. with detrital chert in the sands. The Fredonia Member measures a total exposed thickness of $11.4 \mathrm{~m}$. traced through the stream canyon, with a very steep floor gradient, and ending in a waterfall. The Lost River Chert Bed is exposed as a resistent ledge below the lip of the waterfall.

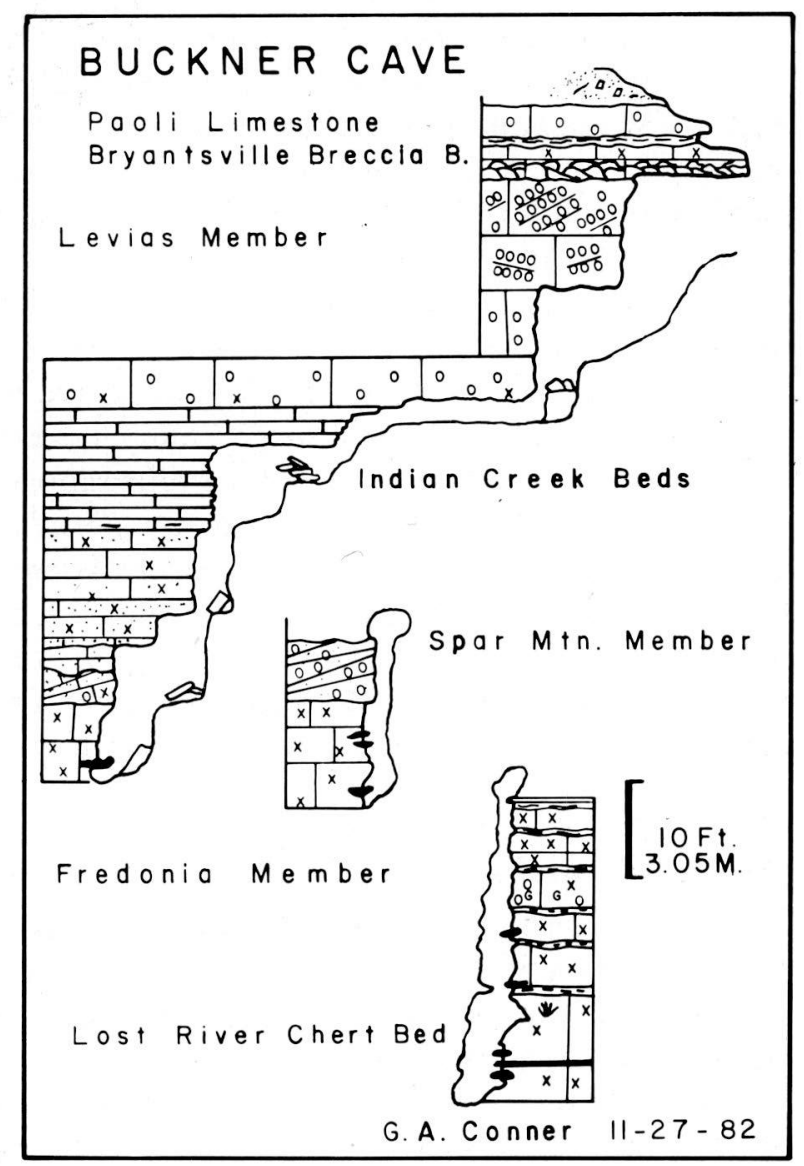

Fig. 9 - Buckner Cave section.

G. A. Conner 11-27-82 
The Triple J Cave section (Fig. 10) lies $900 \mathrm{~m}$. south of the Buckner Cave entrance and is estimated to lie at an elevation of $245 \mathrm{~m}$. mean tide. One meter of Paoli limestone is exposed inside the entrance in the sinkhole. On a ledge $36.6 \mathrm{~cm}$. of sandstone is exposed which is identified as the Popcorn Bed, the best development of the Popcorn in the Garrison Chapel area. Alternatively, this sandstone may be considered to be the upper sandstone exposed in Shaft Cave and consequently the identification of the Paoli Limestone at Triple J would be affected. At Triple J the Bryantsville Breccia Bed is not recognized. Considering the observation that the Popcorn Bed is much more thickly developed several miles southeast of Triple J Cave and the exceptionally thick oolitic section in the upper Levias Member at Triple J where the Bryantsville is absent it is preferrable to refer the sandstone of question to the Popcorn horizon. The Levias Member is unusually thick measuring 12.0 meters attributable to a thick upper oolitic section; perhaps near the center of a convex oolite body. The Indian Creek Beds below measure 3.6 meters and rest directly on a sandy breccia bed marking the top of the Spar Mountain Member. Chert sand is also present in the breccia, however the section is different than at the Signature Room in Buckner Cave. In Triple J Cave the Spar Mountain measures $4.7 \mathrm{~m}$. to the floor at the entrance. Below the sandy breccia section lies 3.2 meters of micritic lime with sparse chert nodules. Farther downstream the lower Spar Mountain Member was recognized beyond Aqua Avenue at survey stations $\mathrm{C} 5$ and $\mathrm{C} 11$ through to the Cherty Channel. There a $0.5 \mathrm{~m}$. thick green sparry gastropod and brachiopod limestone capped by a $15.2 \mathrm{~cm}$. silty clay bed is recognized as the lower boundary of the Spar Mountain Member overlying a micritic limestone with concentrations of chert nodules representing the upper Fredonia. This same silty clay bed and gastropod limestone association is observed four miles to the southeast in the Mountain Room and Blue Pool Canyon in Reeves Cave. Total thickness o the Spar Mountain Member in Triple J was not determined.

\section{SUMMARY OF CORRELATIONS}

Correlation of the reference cavern sections in the Garrison Chapel karst area to the units of Indiana out-crops is established by recognition of the Indian Creek Beds in the lower Levias Member which are recognized twenty miles away at the Cataracts on Mill Creek where MALOTT (1946) subdivided the Ste. Genevieve Formation in Indiana. Additionally MALOTT (1952, p. 57) described the lithographic beds now named Indian 
Creek Beds where they appear in the "old tunnel section" three miles east of the Garrison Chapel area.

The entire stratigraphic interval of the Spar Mountain Member was measured downward from the base of the Indian Creek Beds in Shaft, Grotto, and Buckner revealing an average thickness of $7.3 \mathrm{~m}$., with a maximum of $10.4 \mathrm{~m}$. in Shaft and a minimum of $4.9 \mathrm{~m}$. in Buckner.

The upper portion of the Levias Member, the oolitic and bioclastic beds, overlying the Indian Creek Beds was measured in all five secions averaging $6.7 \mathrm{~m}$. except for a thickness of $8.3 \mathrm{~m}$. in Triple J entrance which is interpreted as the center of a convex oolite bar.

The upper sandstone near the top of Shaft Cave entrance is $7 \mathrm{~m}$. above a shaley bed interpreted as the Popcorn Bed of Swann. The intervening oolitic limestone is lower Paoli and the sandstone is agreeably equivalent to either the Basin Aux Vases sandstone or the higher Renault sandstone. The micritic limestone above is upper Paoli and confirmed by a thick massive sandstone higher on the slope; the Mooretown of Indiana out-crops or the Bethel of Basin useage. Two kilometers to the west on the Leininger farm $6.8 \mathrm{~m}$. of Bethel sandstone was logged between the Beaver Bend and

Fig. 10 - Triple J Cave section.

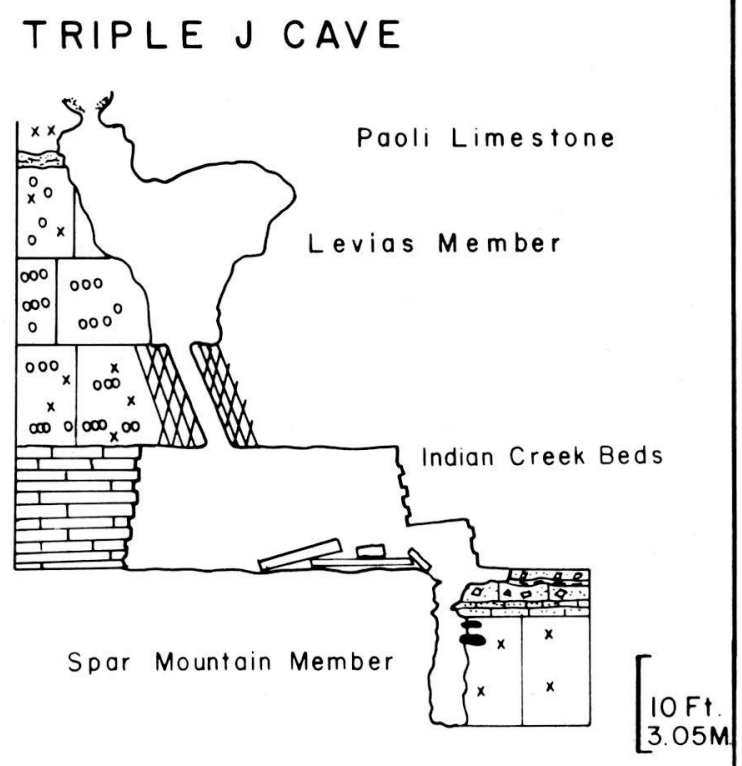

G. A. Conner $2-19-83$ 
Paoli limestone in Indiana Geological Survey Drillhole No. 155. Bethel sandstone in the area is consistently more than 3.6 meters thick in known exposures.

Correlation of the individual beds within the Ste. Genevieve Formation and the Paoli Limestone in the Garrison Chapel area and karst valley is relatively straighforward with exception to the thin clastic beds within the Paoli Limestone which may be locally discontinuous within the area of an individual cave system.

\section{REFERENCES}

BEEDE J.W., 1911. The cycle of subterranean drainage as illustrated in the Bloomington, Indiana Quadrangle: Indiana Acad. Sci. Proc., v. 20, p. 81-111, 32 figs.

CONNER G.A., 1986. Type section for Indian Creek Beds in the Ste. Genevieve Formation of South-Central Indiana: in press, Indiana Acad. Sc. Proc., v. 95.

GRAY H., JENKINS AND WEIDMAN, 1960. Geology of the Huron area, south-central Indiana: Ind. Geol. Surv. Bull. 20, 78 p., 2 pls., 4 figs., 7 tables.

Malott C.A., 1919. The American Bottoms Region of Eastern Greene County, Indiana: Ind. Univ. Studies No. 40: 45.

MALOTT C.A., 1922. The physiography of Indiana, in Handbook of Indiana geology: Indiana Dept. Conserv. Pub. 21, pt. 2, p. 59-256, 3 pls., 51 figs.

MalotT C.A., 1946. The geology of Cataract Falls, Owen County, Indiana: Jour. Geology, v. 54, p. 322-326, 2 figs.

MALOTT C.A., 1952. Stratigraphy of the Ste. Genevieve and Chester formations of southern Indiana: Ann Arbor, Mich., Edwards Letter Shop, 105 p.

MARSHALL R.B., 1910. Bloomington, Indiana Quadrangle. U.S. Geological Survey 15 minute series.

National Speleolgical Society, 1973. Convention Guidebook: Bloomington, Indiana Grotto.

PERRY T.G., AND SMITH N.M., 1958. The Meramec-Chester and intra-Chester boundaries and associated strata in Indiana: Indiana Geol. Surv. Bull. 12, 110 p., 6 pls., 1 fig.

Powell R.L., 1960. Caves of Indiana: Indiana Geol. Surv. Circ. 8, 127 p., 4 pls. 58 figs.

SHAVER R.H. ET AL., 1970. The Indiana compendium of rock-unit stratigraphy: Indiana Geol. Surv. Bull. 43, p. 143.

SwanN D.H., 1963. Classification of Genevievian and Chesterian (late Mississippian) rocks of Illinois: Illinois Geol. Surv. Rept. Inv. 216, 91 p.

WAYNE W.J., 1949. A karst valley in western Monroe County, Indiana: Indiana Acad. Sci. Proc., v. 58, p. 258-263, 2 figs. 